American Journal of Applied Sciences 5 (12): 1713-1719, 2008

ISSN 1546-9239

(C) 2008 Science Publications

\title{
Economic Sanctions, Oil Price Fluctuations and Employment: New Empirical Evidence from Libya
}

\author{
${ }^{1}$ Abdusalam Faraj Yahia and ${ }^{2}$ Ali Salman Saleh \\ ${ }^{1}$ School of Economics, University of Wollongong, NSW 2522, Australia \\ ${ }^{2}$ Faculty of Business and Law, School of Applied Economics, Victoria University
}

\begin{abstract}
This research attempts to examine the links between fluctuating oil prices, economic sanctions and the employment in the Libyan economy. In particular, this study attempts to answer the basic question whether UN's resolutions number 748 (1992) of 31 March 1992 and oil price fluctuations have any significant influence on the employment in Libya. One of this study's key findings is that fluctuating oil prices and economic sanctions have strongly affected both the Libyan and non-Libyan employees. The periods of sharp decline in oil prices (1983-1998) and economic sanctions (1990-2003) had a negative impact on the movement of skilled non-Libyan workers. This resulted in a huge loss of this type of labour, which is almost impossible to replace in the short term. It could also negatively affect various other sectors in the country, such as oil production and industry, among others. In addition, our cointegration results show that there is no evidence of long run relationship between the non-Libyan employees and fluctuating oil prices in Libya. This research brought a new empirical evidence on the relationship between fluctuating oil prices, economic sanctions and the employment in the Libyan economy. It also provides important policy implications for the Libyan government, the Security Council and multinational companies. JEL classification: C22, E20, E30.
\end{abstract}

Key words: Economic sanctions, oil prices, employment, cointegration, Libya

\section{INTRODUCTION}

Libya is a small oil-producing developing economy in North Africa and its economy is heavily dependent on oil revenue. Libya plays an important role as a member of OPEC in the supply of oil to the world market.

Conditions in the Libyan economy worsened in the 1990 s as a result of international sanctions that were imposed by United Nations in the earlier $1990 \mathrm{~s}^{[41]}$. According to paragraph 4 of UN's resolution 748 (1992): All states shall deny permission to any aircraft to take of from, land in or over flay their territory if it is destined to landing in or has taken off from the territory of libya, unless the particular flight has approved on grounds of significant humanitarian need by SC. It has also stated in paragraph 5 and 6 that: (i) all states shall prohibit any provision to Libya by their nationals or from their territory of technical advice, assistance or training related to the provision, manufacture, maintenance, or use of the items explained in paragraph 5 article (a). (ii) All states shall significantly reduce the number and the level of the staff at Libyan diplomatic mission and consular posts and restricts or controls the movement within their territory of all such staff who remains in the case of Libyan mission ${ }^{[41,42]}$.

This research examines the impact of economic sanctions on Libyan economy and attempts to answer the basic question that has been introduced by Allen ${ }^{[3]}$ do sanctions work? In particular, this research attempts to answer the question whether UN's resolutions number 748 (1992) of 31 March 1992 and oil price fluctuations have any significant influence on the employment in Libya.

The rest of the research is structured as follows. Sections 2 and 3 briefly review the relationship between oil prices, economic sanctions and the employment in the Libyan economy. Section 4 discusses the methodology and reports the empirical findings. Section 5 examines the long-run relationship between the employment and oil prices. The final section presents a conclusion and some policy implications.

\section{A BRIEF REVIEW OF ECONOMIC SANCTIONS, OIL PRICES AND THE EMPLOYMENT IN LIBYA}

The majority of previous studies focus theoretically on the impact of economic sanctions on the political

Corresponding Author: Abdusalam Faraj Yahia, School of Economics, University of Wollongong, NSW 2522, Australia, Tel: +61-0401413963, Fax: +612-42213725 
and economical stability of the state. For example, Niblock $^{[38]}$ argued that economic sanctions could have an inverse impact on the social basis necessary for democratization (p. 64). He argued as well that the multilateral sanctions could widen the gap between rich and the poor. In other words, these sanctions could benefit some and damage others within the country's population. The sanctions possible to accomplish success when the following criteria are fulfilled if the target countries face economic losses that exceed more than $2 \%$ of their GDP; or they have a vital trade relationship with the sender countries ${ }^{[14]}$. We believe that these criteria have already satisfied in the case of Libya. Furthermore, Niblock ${ }^{[38]}$ pointed out that economic sanctions could weaken the political stability of the states on which they are forced over the long run and could affect the wider region. On the other hand, Collins ${ }^{[11]}$ argued that the application of multilateral sanctions could force the country on which was imposed to discontinue its support for terrorism program. According to Niblock ${ }^{[38]}$ economic sanctions are less costly in terms of finance in comparison with war, which damages the country's infrastructure and development. In addition to that, economic sanctions tend to make the country's population to be more reliant on the government. In other words, people will depend more on the government in order to survive or maintain their basis supplies. Therefore, sanctions could support regime's ideological legitimacy (p. 64).

Most of the earlier literature has focused on the impact of economic sanctions mainly on the political environment and the country's position in terms of supporting terrorism program. Hence, one of the novelties of this study is to examine economically and empirically the impact of economic sanctions on employment in Libya. In other words, we attempt to determine whether the economic sanctions have any positive or negative impact from the economic point of view.

A few researchers have theoretically discussed the impact of economic sanctions on Libyan economy such as $^{[6,25,28,38,51]}$.

The Libyan economy suffered for an extended time from strong economic sanctions imposed by the US (for example, during the 1980s, which were re-enforced in the 1990s); the UK in 1984 and by the UN in $1992^{[6]}$. Furthermore, Stephen ${ }^{[14]}$ argued that multilateral sanctions seem to have caused Libya's removal from the position of terrorism sponsors. Hochman ${ }^{[25]}$ examined the December 2003 decision that has been made by the Libyan government to dismantle nonconventional weapons program. He concluded that economic sanctions and the US invasion of Iraq are the main reasons for this Libyan decision ${ }^{[28]}$.
Since the ending of the UN's sanctions in $2003^{[43]}$, Libya has rejoined the international community and has been implementing measures to reform and open up its economy, but progress in developing a market economy has been slow and erratic. Libya needs strong and sustained economic growth to meet the needs of its rapidly growing labour force, which requires high investment in physical and human capital and a more efficient use of the country's resources. However, fluctuating oil prices will affect the achievement of these objectives.

Many researchers has focused on the relationship between oil prices and various macroeconomic variables, such as GDP, employment, investment $^{[9,23,24,37,45,46]}$. According to these authors, the impact of oil price fluctuations on economic activity can be statistically estimated, measured and classified.

Many researchers pointed out that oil price fluctuations can exert a significant influence on economic activity through different channels, including the labour market ${ }^{[10,12,17,26,27,20,21]}$.

Several researchers have examined the impact of oil price fluctuations on economic growth and the performance of the Libyan economy ${ }^{[1,2,33,49,48,50]}$. These researchers have concluded that the Libyan economy was severely affected by oil price fluctuations because of its heavy dependence on oil revenues.

A comprehensive literature on the impact of oil prices fluctuation on the Libyan economy can be found in Yahia and $\mathrm{Ali}^{\left[{ }^{[4]}\right.}$ and Yahia and Metwally ${ }^{[49]}$.

Hence, the majority of previous studies have focused on the effect of oil prices on aggregate employment. While our study attempts to provide new evidence on disaggregated levels. The other aims could be summarized as below:

- We examine the impact of fluctuating oil prices and economic sanctions on the local workers in Libya. It is important to know whether fluctuating oil prices and economic sanctions exert a significant impact on local workers.

- The second part of our study evaluates the impact of changes in oil prices and economic sanctions on the foreign workers in Libya. By investigating the interaction of oil prices, economic sanctions and the non-Libyan workers, we hope to shed some light on the effect of oil prices and economic sanctions on foreign workers in Libya. Further, it will allow us to draw a clear picture of the government's role regarding fluctuating of oil prices or the economic stability of the country. 
Am. J. Applied Sci., 5 (12): 1713-1719, 2008

Table 1: Libyan population

\begin{tabular}{|c|c|c|c|c|}
\hline Year & 1972 & 1980 & 1998 & 2005 \\
\hline $\begin{array}{l}\text { Total Population } \\
\text { (thousand persons) }\end{array}$ & 2,150 & 3,246 & 5,101 & 5,850 \\
\hline $\begin{array}{l}\text { Nationals } \\
(92 .)\end{array}$ & $1,888(87.8)$ & 2,805 & $4,590(89.9)$ & 5438 \\
\hline Expatriates & $262(12.2)$ & $441(13.5)$ & $511(10.1)$ & $412(7.1)$ \\
\hline
\end{tabular}

Note: figures between parentheses are percentages out of total population.

Sources: collected by the authors based on ${ }^{[32,35,4,7]}$.

\section{LIBYAN POPULATION AND EMPLOYMENT}

Table 1 reports the composition of the Libyan population over the period 1972-2005 and shows that it increased from 2.15 million persons in 1972 to 5.8 million in 2005. The growth rate of the Libyan population was estimated at 4.1 per cent during the period $1975-1995^{[48]}$. Table 1 also reveals that Libyan's dependence on expatriates to conduct its economic activities declined sharply over the last two decades. This is because the Libyan fertility rate is one of the highest among OPEC members, after Saudi Arabia and Iraq $^{[\mathrm{UN}, 47] \text {. }}$

\section{MATERIALS AND METHODS}

This study uses data covering the period 19702005 , which was obtained from various local, regional and international sources ${ }^{[32,35,7,8,31,39 \text {, and } 40]}$ to analyse the impact of economic sanctions and fluctuations in oil prices on the employment in Libya. The analysis focuses on the periods of various fluctuations in oil prices: 1972-1982, 1983-1998, and 1999-2005 and the whole period of 1970-2005.

No empirical research exists on the impact of fluctuation in oil prices and economic sanctions on the Libyan and non-Libyan employees. Neither are there extant empirical studies that investigate the long-run relationship between oil prices and the employment in the Libyan economy. This study has two main objectives:

- To identify a model that allows us to determine the dynamic linkages between oil prices, an economic sanctions and employment in the Libyan economy.

- To apply the Johansen procedure, (Johansen and Juselius $^{[30]}$ in order to examine the long-run relationship between these variables.

Our conceptual framework is based on earlier studies (especially the relationship between the employment and oil prices), including $\mathrm{Uri}^{[46]}$, Brown and Hill ${ }^{[10]}$ Davise et al. ${ }^{[12]}$, Evangelia ${ }^{[17]}$, Hunt et al. ${ }^{[26]}$,
Iledar ${ }^{[27]}$, Gil-Alan ${ }^{[20,21]}$. These investigate the impact of oil price fluctuations on employment in various countries. Hence, drawing on the existing literature and following Hamilton's recommendation ${ }^{[24]}$ we specify the following multiple regression models that allowed us to identify the impact of fluctuating oil prices and economic sanctions on the employees movement in the Libyan economy.

$$
\begin{aligned}
& \mathrm{LL}_{\mathrm{t}}=\mathrm{b}_{0}+\mathrm{b}_{1}\left(\mathrm{Lp}_{\mathrm{t}}\right)+\mathrm{b}_{2}\left(\mathrm{LL}_{\mathrm{t}-1}\right)+\mathrm{D}_{\mathrm{t}}+\mathrm{u}_{\mathrm{t}} \\
& \mathrm{LNL}_{\mathrm{t}}=\mathrm{b}_{0}+\mathrm{b}_{1}\left(\mathrm{LP}_{\mathrm{t}}\right)+\mathrm{b}_{2}\left(\mathrm{LNL}_{\mathrm{t}-1}\right)+\mathrm{D}_{\mathrm{t}}+\mathrm{u}_{\mathrm{t}}
\end{aligned}
$$

Where, $\mathrm{LL}_{\mathrm{t}}$ represents the $\log$ of the local labour in Libya and $\mathrm{Lp}_{\mathrm{t}}$ represents oil prices at constant prices $(2000=100)$. The lagged dependent variable gives the equations a dynamic character, allowing for partial adjustment (or lagged affects), following Koyck's geometrically declining weight scheme Guiarati ${ }^{[22]}$ $\mathrm{LNL}_{\mathrm{t}}$ Represents the log of non-Libyan workers. The error term in each equation is explained by $\mathrm{u}_{\mathrm{t}}$ and the dummy variable $D_{t}$ (as suggested by Hamilton ${ }^{[24]}$ measures the external shock of economic sanctions (where $D_{t}=1$ during 1990-2003 and $D_{t}=0$ otherwise).

The regression results for the two models are given in Table 2 and 3. However, as shown in these tables, the two equations are well fitted, as evident from the values of $R^{2}$ and the $t$ statistics (shown under each coefficient). The Durbin $\mathrm{h}$ statistic was measured in periods of more than 30 observations ${ }^{[22,44]}$. However, during the period 1970-2005 the h statistic does not show any significant problem of serial correlation at the five per cent level of significance.

The data in Table 2 suggests that the coefficient of the variable $\mathrm{Lp}_{\mathrm{t}}$, which represents the oil prices in real terms, was statistically significant in all periods, with the exception of the period 1972-1982. The significant lagged oil price variable suggests the existence of a partial adjustment mechanism in all cases, with the exception of the period 1999-2005. This finding can be explained by the relatively significant effect of the economic sanctions represented by the coefficient $D_{t}$, or it could be explained by the economic reforms applied by the government after these sanctions were frozen. The relatively higher value of the coefficient $D_{t}$ in Table 2, in comparison with the data in Table 3, supports the substitution of foreign workers by local workers.

The regression results in Table 3 suggest that nonLibyan labour in the Libyan economy was growth driven during the boom period of 1972-1982 and in the whole period of 1970-2005. The coefficient $b_{1}$ indicates 
Am. J. Applied Sci., 5 (12): 1713-1719, 2008

Table 2: Libyan labor and oil prices in real term (\$)

\begin{tabular}{lllll}
\multicolumn{5}{c}{$\mathrm{LL}_{\mathrm{t}}=\mathrm{b}_{0}+\mathrm{b}_{1}\left(\mathrm{Lp}_{\mathrm{t}}\right)+\mathrm{b}_{2}\left(\mathrm{LL}_{\mathrm{t}-1}\right)+\mathrm{D}_{\mathrm{t}}+\mathrm{u}_{\mathrm{t}}$} \\
\hline & $\hat{\mathrm{b}}_{0}$ & $\hat{\mathrm{b}}_{1}$ & $\hat{\mathrm{b}}_{2}$ & $\mathrm{D}$ \\
\hline $1972-1982$ & -0.58 & 0.09 & 0.14 & \\
& $(-0.53)$ & $(.17)$ & $\left(4^{*}\right)$ & \\
& $\mathrm{R}^{2}=0.89$ & $\mathrm{~F}=34$ & & \\
$1983-1998$ & 2 & -0.12 & 0.73 & \\
& $(1.4)$ & $\left(-1.6^{* * *}\right)$ & $(3.7 *)$ & \\
& $\mathrm{R}^{2}=0.85$ & $\mathrm{~F}=39$ & & \\
$1999-2005$ & 2.5 & -0.64 & 0.82 & \\
& $(.68)$ & $\left(-1.8^{* * *}\right)$ & $(1.5)$ & \\
$1970-2005$ & $\mathrm{R}^{2}=0.46$ & $\mathrm{~F}=1.74$ & & \\
& 1.4 & 0.043 & 0.75 & \\
& $(3.6)$ & $(1.4 * *)$ & $\left(11^{*}\right)$ & \\
& $\mathrm{R}^{2}=0.94$ & $\mathrm{~F}=170$ & $\mathrm{~h}=1.6$ & $0.20\left(3.2^{*}\right)$ \\
\hline
\end{tabular}

Notes: $* * *, * * *$ indicate the $\mathrm{t}$ values at levels $10 \% ; 5 \%$ and $1 \%$ respectively

Table 3: Non-Libyan Labor and oil prices in real term (\$) $\mathrm{LNL}_{\mathrm{t}}=\mathrm{b}_{0}+\mathrm{b}_{1}\left(\mathrm{LP}_{\mathrm{t}}\right)+\mathrm{b}_{2}\left(\mathrm{LNL}_{\mathrm{t}-1}\right)+\mathrm{D}_{\mathrm{t}}+\mathrm{u}_{\mathrm{t}}$

\begin{tabular}{lllll}
\hline & $\hat{\mathrm{b}}_{0}$ & $\hat{\mathrm{b}}_{1}$ & $\hat{\mathrm{b}}_{2}$ & $\mathrm{D}$ \\
\hline $1972-1982$ & 1.8 & 0.31 & 0.55 & \\
& $(2.7)$ & $\left(1.8^{* *}\right)$ & $\left(2.9^{*}\right)$ & \\
& $\mathrm{R}^{2}=0.91$ & $\mathrm{~F}=42$ & & \\
$1983-1998$ & 1.5 & -.007 & 0.68 & \\
& $(1.8)$ & $(-.028)$ & $\left(3^{*}\right)$ & \\
& $\mathrm{R}^{2}=0.65$ & $\mathrm{~F}=12$ & & \\
$1999-2005$ & 6.5 & -.48 & -0.15 & \\
& $(1.3)$ & $(-.41)$ & $(-0.22)$ & \\
$1970-2005$ & $\mathrm{R}^{2}=0.044$ & $\mathrm{~F}=.09$ & & \\
& 2 & 0.21 & 0.53 & \\
& $(3.9)$ & $(1.5 * *)$ & $\left(4.2^{*}\right)$ & \\
& $\mathrm{R}^{2}=0.68$ & $\mathrm{~F}=22$ & $\mathrm{~h}=1.8$ & $0.19\left(-1.8^{* *}\right)$ \\
\hline
\end{tabular}

Notes: $* * *, * *, *$ indicate the $\mathrm{t}$ values at levels 10,5 and $1 \%$ respectively

that an increase in oil price by one percent led to an increase in foreign workers by approximately $30 \%$. The lagged $\mathrm{LNL}_{\mathrm{t}-1}$ variable (representing all lagged oil prices via Koyck's geometrically declining weight assumption) is statistically significant at least at one per cent and five per cent levels in all periods, with the exception of the period 1999-2005. Accordingly, it can be said that non-Libyan workers benefited from opportunities generated by increases in oil prices during the boom periods. The coefficient of the $D_{t}$ variable that represents the impact of the sanctions on the foreign workers is statistically significant. In other words, more than 65 per cent of the fluctuation in the non-Libyan workers can be explained by economic sanctions, fluctuating oil prices and lagged oil prices.

\section{LONG-TERM RELATIONSHIP BETWEEN THE EMPLOYMENT AND OIL PRICES IN LIBYA}

This study examines whether there is a long-term relationship between oil prices and the employment in the Libyan economy. If such a relationship exists, then
Table 4: Unit Root Test of Various Components of Labor Market in the Libyan Economy 1970-2005

\begin{tabular}{llll}
\hline Variable & ADF & & \\
& - & & \\
& Level & $1^{\text {st }}$ Diff & $5 \%$ Level \\
\hline LL & -1.541460 & -4.028337 & -2.948404 \\
LNL & -2.769857 & -5.269445 & -2.948404 \\
LP & -2.326194 & -5.729706 & -2.948404 \\
\hline
\end{tabular}

the two variables may not drift too far apart from each other over time. In other words, there may be evidence of cointegration between the two variables. This could imply that growth in the labour market in Libya is simply a reflection of fluctuating oil prices. However, if there is no evidence of cointegration, the relative magnitude of the Libyan employment could be increased or decreased over time due to reasons such as the devaluation of the local currency, economic sanctions or government policies.

This research utilizes the cointegration procedure to examine the long-term relationship between the employment in Libya and oil prices. According to Engle and Granger ${ }^{[15]}$ two variables will be cointegrated if they have a long-term relationship or equilibrium. Thus, if a long-run relationship exists, the two variables must form a unique cointegrating vector.

In order to test for cointegration and in particular, to examine whether a unique cointegrating vector can be identified, this study applied the maximum likelihood estimation technique developed by Johansen $^{[29]}$, Johansen and Juselius ${ }^{[30]}$.

The first stage in conducting this approach is to determine the order of integration of each variable included in the model. The common practice is to apply the augmented Dickey-Fuller test (ADF) given by the following equation for variable $\mathrm{Z}$.

$$
\Delta Z_{t}=\alpha_{1}+\alpha_{2} t+\rho Z_{t-1}+\rho_{1} \sum_{i=1}^{k} \Delta Z_{t-i}+\varepsilon_{t}
$$

Where, $\varepsilon_{\mathrm{t}}$ is an error term (Dickey and Fuller ${ }^{[13]}$.

The cumulative distribution of the ADF test statistic is provided by Mackinnon ${ }^{[34]}$ If the calculated (absolute) statistic is greater than its critical value, then $\mathrm{Z}$ is said to be stationary or $\mathrm{I}(0)^{[22]}$.

Table 4 reports the results of the augmented Dickey-Fuller test. The estimation is based on 36 observations for the period 1970 to 2005. The augmented Dickey-Fuller regressions include an intercept and a linear trend. It is clear that the calculated (absolute) statistics are greater than the critical value for the variables representing LL, LNL, and LP only for the differenced variables. This indicates the non- 
Am. J. Applied Sci., 5 (12): 1713-1719, 2008

Table 5: Johansen-Juselius Cointegration results between Oil Prices and employment in Libyan Economy

\begin{tabular}{|c|c|c|c|c|c|c|c|}
\hline variable & Null & Alter-native & $=$ MAX $\lambda$ 2-lag 3-lag & C. Value $95 \% 90 \%$ & Alter-native & TRACE 2-lag 3-lag & C. Value $95 \% \quad 90 \%$ \\
\hline LLI & $r=0 r<=1$ & $r=1 r=2$ & $15.6924 .605 .96 \quad 8.03$ & $\begin{array}{lllll}18.33 & 16.28 & 11.54 & 9.75\end{array}$ & $\mathrm{r}=0 \mathrm{r}<=1 \mathrm{r}>=1 \mathrm{r}=2$ & $21.6632 .645 .96 \quad 8.03$ & $23.83 \quad 21.23 \quad 11.54 \quad 9.75$ \\
\hline LNLI & $\mathrm{r}=0 \mathrm{r}<=1$ & $r=1 r=2$ & 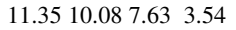 & $18.3316 .28 \quad 11.54 \quad 9.75$ & $\mathrm{r}=0 \mathrm{r}<=1 \mathrm{r}>=1 \mathrm{r}=2$ & $18.913 .637 .63 \quad 3.54$ & $23.821 .23 \quad 11.54 \quad 9.75$ \\
\hline
\end{tabular}

stationary nature of these variables at that level and shows that the variables have become stationary after being differenced once. Thus, the variables are integrated of order one I(1). This fact enables us to conduct the cointegration analysis ${ }^{[30]}$. This result suggests a maximum likelihood estimation procedure which provides two test statistics for determining the number of cointegrating vectors which could exist among a set of variables.

The trended case, with a trend in DGP, which has higher critical values, was considered in this analysis. The first step was to specify a lag length for the VAR, on the basis of the likelihood ratio test. In order to test the sensitivity of the results for choice of lags, we tried different lag orders. According to our annual data, the method was applied using one, two, three and four VAR lags. However, the two and three lags produced the best results, which are reported in Table 5 .

Table 5 reports the co integration results for the long-term relationship between the oil prices and employment in Libya.

The results in Table 5 show that the LR tests based on the maximal eigen value of the stochastic matrix and the trace of the stochastic matrix suggest that the null hypothesis of no cointegration is strongly rejected in the case of variables LL by both the $\lambda$-max and the trace test. In contrast, the null hypothesis of no cointegration between oil prices and the non-Libyan workers cannot be rejected by both $\lambda$-max and trace tests, indicating the lack of cointegration between two variables.

Furthermore, as shown in Table 5, the results are quite sensitive to the choice of lags in all cases, with the exception of non-Libyan workers. The finding of no long-run relationship between oil prices and foreign workers in Libya can be explained by the fact that increasing or decreasing the number of foreign employees in the Libyan economy is subject to the political stability there, reflected in government caps, rather than fluctuating oil prices. This could be explained by the fact that small proportion of foreign workers are working in Libya, or the strong effect of economic sanctions imposed during 1992-2003. This finding also supports the conclusions reached by Keibah $^{[33]}$ and Bhairi ${ }^{[7]}$ : that the shortage of labour in Libya allowed the proportion of foreign workers from different regions to increase sharply during the oil boom of 1972-1982.

\section{CONCLUSION AND POLICY IMPLICATIONS}

This study was motivated by the need for an indepth empirical analysis determining the impact of fluctuating oil prices and economic sanctions on the Libyan and Non-Libyan workers in Libya. We used a specified multiple regression model and cointegration procedure analysis to examine the relationship between these variables and to identify whether this relationship exists in the long term.

Our results from the regression models suggest that oil prices exert a significant impact on the labour market in Libya. Oil prices positively affected Libyan and non-Libyan employees during the period 19721982. Oil prices also negatively affected the labour market in Libya during the recession period 1983-1998. The significance of the lagged veraible of oil prices also suggests the existence of a partial adjustment mechanism in all cases. The Johanson-Juselius approach of cointegration also suggests the existence of a long-run relationship between oil prices and employment in the case of local workers in Libya.

The dummy variable, which represents external shocks, suggests that economic sanctions have negatively affected non-Libyan workers. As a result, around $20 \%$ local workers replaced $18 \%$ foreign workers. Thus, the hypothesis that United Nations sanctions have had a negative impact on the labour market in Libyan cannot be rejected.

Our results also show that there is no evidence of a long-term relationship between oil prices and the number of foreign workers in Libya. This finding can be explained by the fact that the number of foreign workers was subject to government caps and economic sanctions imposed on the country during the 1990s.

Some key policy implications regarding the fluctuations in oil prices and economic sanctions can be summarised as follows:

1. Libyan policy makers should be aware that fluctuations in oil prices could have a severe impact on the movement of the labour and result in a huge loss of skilled non-Libyan workers. Therefore, Libyan authorities should plan for such losses' impact on certain economic sectors. This might include training and educating the local 
workers through government and private sector programs, in order to replace the shortage of skilled foreign workers.

2. Our results indicate that economic sanctions, fluctuations in oil prices and instability in the Libyan economy have had adverse effects on the non-Libyan workers. Multinational companies could also suffer from the loss of skilled nonLibyan workers. Multinational companies should plan for such situations when considering operating in countries, which are susceptible to economic instability and are heavily dependent on oil revenues.

3. According to our analysis, the hypothesis that the fluctuation in oil prices and UN's sanctions have had a significant impact on the employment in Libyan economy cannot be rejected. Therefore, this research could provide an advice to the International Community in general and to the Security Council in particular that economic sanctions could be a useful preferable tool in comparison with war and in certain cases could be effective.

\section{ACKNOWLEDGEMENT}

An earlier draft of this research was presented at the Forty-Eight Annual Conference of the New Zealand Association of Economists held in Christchurch on June 27-29, 2007. The authors would like to thank Dr. Arlene Ozanne from University of Otago for her constructive comments; the Research Student Centre and Professor Rob Castle from University of Wollongong for his invaluable comments. Any errors in the research are the responsibility of the authors.

\section{REFERENCES}

1. Abohobiel, A.A., 1983. An econometric model for the Libyan economy, 1962-1977. Indiana University, US.

2. Al-Abbasi, M.A., 1991. The effect of oil revenues instability on the oil-based and labor-exporting economies: The case of the Arab region. United States-Missouri, University of Missouri-Columbia.

3. Allen, S.H., 2005. The determinations of economic sanctions success and failure. Intl. Interaction., 31: 117-138.

4. Arab League. Statistical Abstract for Arab Countries, (various issues), Arabic League, Cairo.

5. Altunisik, M.B., 1996. A Rentier State's Response to Oil Crisis: Economic Reform Policies in Libya. Arab Stud. Q., 18 (4): 49-65.
6. Bahgat, G., 2004. Oil terrorism and weapons of mass destruction: The libyan diplomatic coup. J. Soc. Poll. Econ Stud., 29 ( 4): 373-391.

7. Bhairi, A., 1981. Foreign labor in libya. US, Oklahoma State University.

8. B1-Tammar, A., 2003. Investment of labour force in libya. Working paper. Al-Tahadi University. Sert. Libya. pp: 20-70. [In Arabic].

9. Brown, S. and M. Yucel, 1999. Oil prices and US aggregate economic activity a quetion of nonlinearity. Econ and financial Rev, second quarter. pp: 16-23.

10. Brown, S. and K. Hill, 1988. Lower oil price and state employment. Contemp Policy Iss., 6 (3): 60-68.

11. Collins, S.D., 2004. Dissuading state support of terrorism: Strikes of sanctions? (An analaysis of dissuasion measures employed against libya) stud in conflict and terrorism., 27 (1): 1-18.

12. Davis, S. and P. Lougani et al., 1997. Regional labor fluctuations: Oil shocks, Military spending and other driving factors. Intl Finance Discussion pp: 1-63.

13. Dickey, D. and W.A. Fuller, 1979. Distribution of the estimates for autoregressive time series with a unit root. J. Amerc Stat. Association., 74: 427-431.

14. Ellison, S.H., 2001. The impact and effectiveness of multilateral economic sanctions: A comparative study. The Intl J of Human Rights., 5 (1): 81-112.

15. Engle, R.F. and C.W.J. Granger, 1987. Cointegration and error correction: Representation, estimation and testing. Econometrics., 55: 143-159.

16. Esfahani, H.S., 1991. Exports, Imports and economic growth in semi-industrialized countries. J. Develop. Econ., 35 (1): 93-116.

17. Evangelia, P., 2001. Oil prices shocks, stock market, economic activity and employment in Greece. energy Econ., 23: 511-532.

18. Eswar, S.P. and K.P. Michale, 1996. The employment and wage effects of oil price changes: A sectoral analysis. Rev. Eco. Stat., 78 (3): 389-400.

19. Ferreira, A. and A. Aguirre, 2004. Oil prices and unemployment: Empirical Evidence from Brazil. Brazilian J. Appl. Eco., 8 (3): 401-11.

20. Gil-Alana, L.A., 2006. UK unemployment dynamics: A fractionally cointegration approach. Eco. Int., 59 (1): 33-50.

21. Gil-Alana, L.A., 2003. Unemployment and Real Oil Prices in Australia: A fractionally Co integration approach. Appl Eco. Let., 10: 201-204.

22. Gujarati, D., 2003. Basic Econometrics, $4^{\text {th }}$ Edn. McGraw-Hill, New York. 
23. Hamilton, J.D., 1983. Oil and the macro economy since world war II. J. political Econ.,91: 228-248.

24. Hamilton, J.D., 2003. What is an oil shock? J. Econometrics., 113 (2): 363-398.

25. Hochman, D., 2006. Rehabilitating a rogue: Libya's WMD Reversal and Lessons for US Policy. Carlisle Barracks., 36 (1): 63-78.

26. Hunt, B., P. Isard, et al., 2002. The macroeconomic effects of higher oil prices. National Institute. Econ Rev., .17: 87-114.

27. Iledare, O. and W. Olatubi, 2004. The impact of changes in crude oil prices and offshore oil production on the economic performance of us coastal gulf states. The Energy J., 25 (2): 97-113.

28. Jentleson, B.W and C.A. Whytock, 2006. Who won Libya? The force-diplomacy debate and its implications for theory and policy. Intl secuirity., 30 (3): 47-86.

29. Johansen, S., 1988. Stat analysis of cointegration vectors. J. Eco. Dynamic Control.,12: 231-254.

30. Johansen, S. and K. Juselius, 1990. Maximum Likelihood Estimation and Inference on cointegration with Applications to the Demand for Money. Oxford Bull Eco. Stat., 52: 169-201.

31. IMF: Intl Financial Stat Yearbook. Various Issues, Washington, D.C.

32. National Authority for Information and Documentation, Stat yearbook (various issues), Tripoli. Al-Jamahiriya publisher.

33. Keibah, M.S., 1987. An econometric investigation of intl labour migration of equilibrium and disequilibrium. University of Leeds, UK.

34. Mackinnon, J.J., 1991. Critical values for cointegration tests' in long-run economic relationships: Readings in Cointegration, Engle R.F., and C.W. Granger (Eds.). pp: 267-276. Oxford, Oxford University Press:

35. Ministry of Planning., 1995. Economic and social indicator 1970-1994. Jamahiriya publisher, Tripoli, Al-Jamahiriya publisher.

36. Mahmud, M. and A. Russell, 1999. An analysis of Libya's revenue per barrel from crude oil upstream activities, 1961-93. OPEC Rev., 23 (3): 213-249.

37. Mork, K.A., 1989. Oil and macro economy when prices go up and down, an extension of hamilton's results. The J. Political Econ., 97 (3): 740-744.

38. Niblock, T., 2001. The regional and domestic political consequences of sanctions imposed on Iraq, Libya and Sudan. Arab. Stud. Q., 23 (4): 59-67.
39. OPEC., 2006. Oil price Bull. online available at <http://www.opec.org/home/>, [01/04/07].

40. OPEC., 2004-2005. Annual Stat Bull. online available at <http://www.opec.org/home/>, [02/04/06].

41. Security Council., 1992. Resolution N: 731. $<$ http://daccessdds.un.org/doc/RESOLUTION/GE N/NR0/010/90/IMG/NR001090.pdf?OpenElement $>$, [8/10/2007].

42. Security Council., 1992. Resolution N: 748. $<$ http://daccessdds.un.org/doc/RESOLUTION/GE N/NR0/011/07/IMG/NR001107.pdf?OpenElement $>,[8 / 10 / 2007]$

43. Security Council., 2003. Resolution N: 1506. <http://daccessdds.un.org/doc/UNDOC/GEN/N03/ 498/81/PDF/N0349881.pdf?OpenElemen>, [8/10/2007].

44. Studenmund, A., 2000. Using Econometrics A Practical guide. $4^{\text {th }}$ Edn. Addison Wesley, Boston.

45. Tatom, J.A., 1988. Macroeconomic Effects of the 1986 Oil Price Decline. Contemporary Policy Iss., 6: 69-82.

46. Uri, N.D., 1996. Changing crude oil price effects on US agricultural employment. Energy Econ., 18: $185-202$.

47. United Nations. Human Develop Report. (various issues).

48. Yahia, F.A. and S.S. Ali, 2007. The impact of economic sanctions and oil price fluctuations on employment in the Libyan Economy, working paper. has been presented in the 48th Annual Conference of the New Zealand Association of Economists held on 27-28 June 2007, Christchurch.

49. Yahia, F.A. and M.M. Metwally, 2007. Impact of Fluctuations in Oil Prices on Libyan Economic Growth. The Middle East Bus and Econ Rev., 19 (1): 39-55.

50. Yahya, Hussein., 1980. Human Capital Migration from Labor-Rich Arab State to Oil-Rich Arab States and the Consequences for the Jordanian Economy. Oklahoma State University, US.

51. Zoubir, Y.H., 2002. Libyan in US foreign policy: from rogue state to good fellow?. Third World Quarterly., 23 (1): 31-53. 